\title{
Influence of donor demographics on the platelet yield during plateletpheresis - experience of 1100 procedures at a tertiary-care hospital.
}

\author{
Mangwana $\mathrm{S}^{1}$
}

${ }^{l}$ Department of Blood Transfusion Services, Sri Balaji Action Medical Institute,New Delhi, India

\author{
Keywords: \\ Plateletpheresis; \\ Haemoglobin; \\ Total Leucocytes Count; \\ Body Mass Index; \\ Platelet Count; \\ Platelet yield.
}

\begin{abstract}
Background: Transfusion of plateletpheresis is effective for treating patients with platelet related insufficiencies while limiting recipient'sexposure to platelets from multiple donors. A larger yield is obtained when donor has a greater number of initial platelets and separation done in a shorter time. The aim of the study was to analyze the effect of various donors and procedure related parameters on the yield of single donor platelet so that blood donors can be screened effectively in less time.
\end{abstract}

Materials and Methods: One thousand and one hundred plateletpheresis procedures were performed in a tertiary-care super-specialty hospital onFenwal AMICUS machine using closed system kits. Statistical analysis was done to establish cause and effect relationship and to find the extent of relationship between different variables.

Results: Height, weight,BMI, platelet count and total leucocyte count had significant correlation with platelet yield, processing time and blood volume processed while haemoglobin especially in females correlated significantlywith processing time $(\mathrm{p}<0.0001)$ and blood volume processed. Rh "negative" donors had shorter processing time than $\mathrm{Rh}$ "positive" donors while ABO group did not show any correlation with machine variables.

Conclusion: Platelet yield correlated positively with pre-donation count, height, weight and BMI. Haemoglobin correlated with processing time and blood volume processed. Optimization of platelet yield is an emerging issue to identify factors which may help in selecting donors to obtain higher platelet yields in shorter time and consequently better clinical outcome.

\section{INTRODUCTION}

Plateletpheresis is the routine collection of platelets using an automated blood cell separator device, which results in the product Plateletpheresis manufactured from a high

\section{Correspondence:}

Dr. Sadhana Mangwana

Department of Blood Transfusion Services, Sri Balaji Action Medical

Institute, New Delhi, India

E-mail:sadhanamangwana@yahoo.co.in yield of platelets from a single donor. Collection of platelets by apheresis is considered one of the greatest advances in transfusion medicine. It provides an adequate response to rapidly growing demand for blood components. New technology has enabled more often donating platelets than whole blood, reducing the number of leukocytes without filtration. Transfusion of Plateletpheresis is effective for treating patients with platelet related insufficiencies, while 
limiting the recipient's exposure to platelets from multiple donors. Administration of these platelets significantly reduced the risk of allo-immunization. There has been a trend towards the use of single donor platelet (SDP) rather than pooled random donor platelet (RDP) in patient with thrombocytopenia over the last decade. ${ }^{1}$ This trend has been resulted from the observations that SDP is a better platelet product due to less number of donor exposures and consequent reduction in transfusion transmitted diseases, transfusion reactions and possibly allo-immunization..$^{2-4}$ Currently, more than $50 \%$ of platelets are produced by plateletpheresis in developed countries. ${ }^{1}$ In India, because of economic constraints \& limited resources, SDP is not in that much demand till date. ${ }^{5}$

Platelet recovery in the patient is influenced by the transfused dose of platelets, which in turn is dependent on the quality of SDP in terms of platelet yield. ${ }^{6}$ Donor platelet count has a direct impact on the yield of platelets. ${ }^{2}$ Buchholz et al observed that large numbers of voluntary blood donors are deferred due to low weight or low platelet count. ${ }^{7}$ At present blood bank also, a large number of donors willing to donate SDP are deferred due to low platelet count $(<150$ $\mathrm{x} 10^{3} / \mu 1$ ) or low haemoglobin concentration. If donors with suboptimum platelet count $\left(<200 \times 10^{3} / \mu \mathrm{l}\right)$ are deferred, a large number of potential plateletpheresis donors will be excluded from the donor pool \& delay will occur in platelet transfusion in critically bleeding patient.

The collection of platelets by apheresis is considered as a very great progress in transfusion medicine. A larger yield of platelets is obtained if the donor has a greater number of initial platelets and if the separation is done in a shorter time. In Transfusion Medicine, screening for suitable donor for platelet aphaeresis is difficult and time consuming procedure. This might lead to delayed supply of life saving
Single Donor Platelet to critically bleeding patient.

The aim of present study was to analyze the effect of various donor and procedure related parameters on the yield of single donor platelet to help clinicians \& blood bank personnel in selecting appropriate donor for plateletpheresis effectively in less time.

\section{MATERIALS AND METHODS}

A total number of 1100 platelet aphaeresis procedures were performed in a tertiary-care super-specialty hospitalover 24 months i.e. between January 2011 and December 2012 where diverse sections of society are treated. Criteria for the selection of donors were in accordance with rules laid down in Drugs and Cosmetic Act, Ministry Of Health and Family Welfare, Govt. of India. ${ }^{8}$ Blood donors must be 18 to 65 years old and in good health. The plateletpheresis procedures were performed on Fenwal Baxter AMICUS machine using closed system aphaeresis kits following standard operating procedure using ACD as an anticoagulant in the proportion of 1: 10. The end point of the procedure was predefined blood volume of donor to be processed for apheresis procedure which varied from $2500-4200 \mathrm{ml}$.

Pre-donation platelet count, haemoglobin, height, weight, Body Mass index (BMI) and blood groups were included as donor related variables. Platelet yield, processing time and blood volume processed were assessed as procedure related variables.

This study was approved by the Institutional Ethics Committee.

Statistical Analysis-The data has been summarized through frequency distributions and contingency tables along with

Table 1: Pearson Values for Correlation of Donor \& Procedure Related Factors with Yield of SDP in Different Studies

\begin{tabular}{|c|c|c|c|c|c|c|c|c|}
\hline $\begin{array}{c}\text { Pearson } \\
\text { Correlation } \\
\text { (r value) withp } \\
\text { value }\end{array}$ & $\begin{array}{l}\text { Goodnough } \\
\text { et al }\end{array}$ & $\begin{array}{c}\text { Chaudhary } R \\
\text { et al }\end{array}$ & DasSS et al & $\begin{array}{l}\text { Guerrero- } \\
\text { Rivera S et al } \\
\text { - Group A }\end{array}$ & $\begin{array}{l}\text { Guerrero- } \\
\text { Rivera S et al } \\
\text { - Group B }\end{array}$ & $\begin{array}{c}\text { EneinAA \& E A } \\
\text { Hussein et al }\end{array}$ & PatelJ et al & $\begin{array}{l}\text { Present } \\
\text { Study }\end{array}$ \\
\hline Pre-donation PC & $\begin{array}{l}\text { Direct correla- } \\
\text { tion }\end{array}$ & $\begin{array}{c}0.506 \\
(<0.001)\end{array}$ & $\begin{array}{c}0.51 \\
(<0.001)\end{array}$ & 0.554 & 0.758 & 0.512 & $\begin{array}{c}0.302 \\
(<0.0001)\end{array}$ & $\begin{array}{c}0.577 \\
(<0.001)\end{array}$ \\
\hline Pre-donation $\mathrm{Hb}$ & - & $\begin{aligned} &-0.1 \\
&(>0.005)\end{aligned}$ & $\begin{array}{c}-0.05 \\
(>0.005)\end{array}$ & $\begin{array}{l}\text { Inverse correla- } \\
\text { tion }\end{array}$ & $\begin{array}{l}\text { Inverse correla- } \\
\text { tion }\end{array}$ & -0.306 & $\begin{array}{l}-0.001 \\
(>0.05)\end{array}$ & $\begin{array}{c}0.022 \\
(>0.05)\end{array}$ \\
\hline Donor's Height & - & - & - & - & - & - & - & $\begin{array}{c}0.091 \\
(<0.05)\end{array}$ \\
\hline Donor's weight & - & - & 0.18 & - & - & - & $\begin{array}{c}0.023 \\
(>0.05)\end{array}$ & $\begin{array}{c}0.092 \\
(<0.05)\end{array}$ \\
\hline BMI & - & - & - & - & - & - & - & $\begin{array}{c}0.069 \\
(<0.05)\end{array}$ \\
\hline Processing Time & - & - & - & - & - & - & $-0.07(>0.05)$ & $\begin{array}{l}-0.516 \\
(<0.001)\end{array}$ \\
\hline $\begin{array}{l}\text { Total volume } \\
\text { processed }\end{array}$ & - & - & - & - & - & - & $\begin{array}{c}0.158 \\
(<0.05)\end{array}$ & $\begin{array}{c}-0.648 \\
(<0.001)\end{array}$ \\
\hline TLC & - & - & - & - & - & - & - & $\begin{array}{c}0.095 \\
(<0.05)\end{array}$ \\
\hline
\end{tabular}




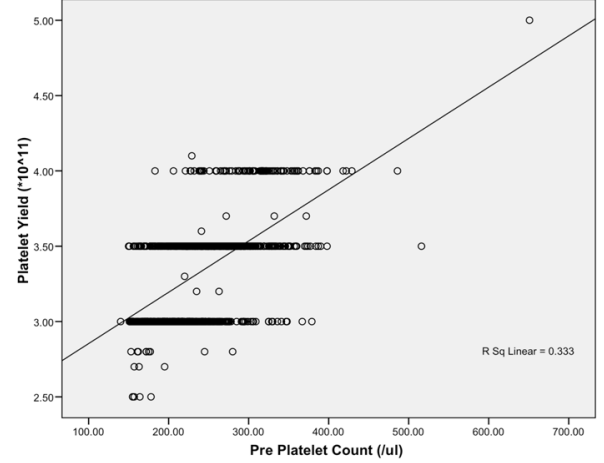

Figure 1: Correlation of Pre-donation Platelet Count with Platelet yield.

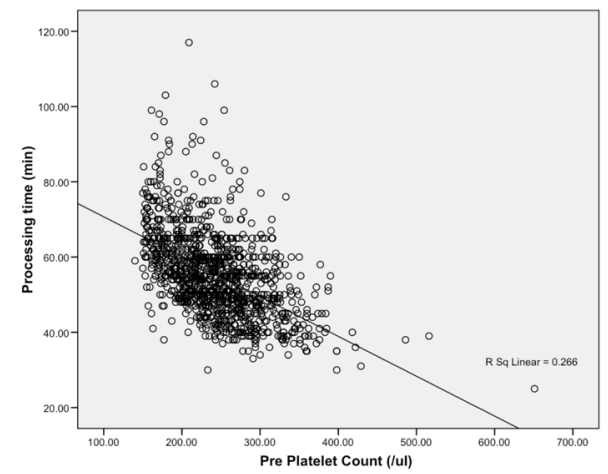

Figure 3: Correlation of pre-donation platelet count with processing time(in minutes)

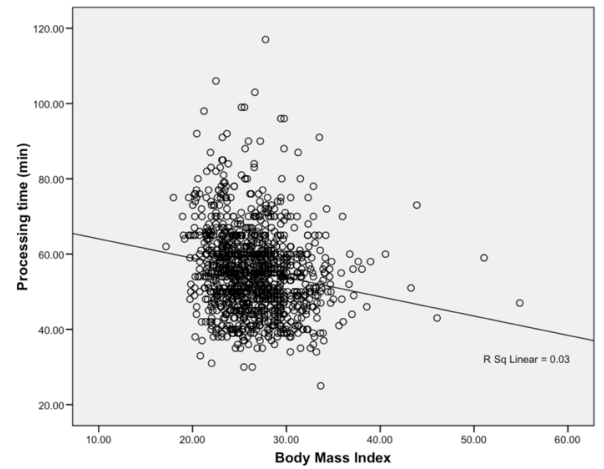

Figure 5: Correlation of Body Mass Index (BMI) with Processing Time (in minutes)

suitable graphs. The statistical analysis was performed using SPSS software Version 15.0 where Pearson Correlation (' $r$ ' value, $p$ value),Mann- Whitney \& ANOVA test and Multivariate analysis using stepwise regression method were used to establish cause and effect relationship and also to find the extent of relationship between different variables.

\section{RESULTS}

A total of 1100 healthy donors met the requirements for plateletpheresis on Amicus Cell Separator of Fenwal, USA with mean body weight of $77.32 \pm 23.53 \mathrm{~kg}$ and mean BMI

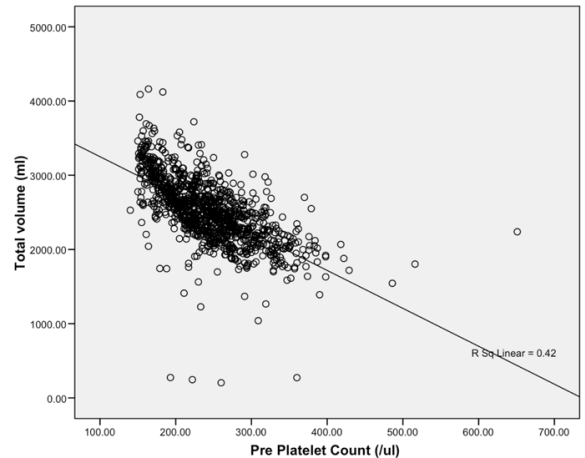

Figure 2: Correlation of Pre-donation platelet count with Total blood volume processed.

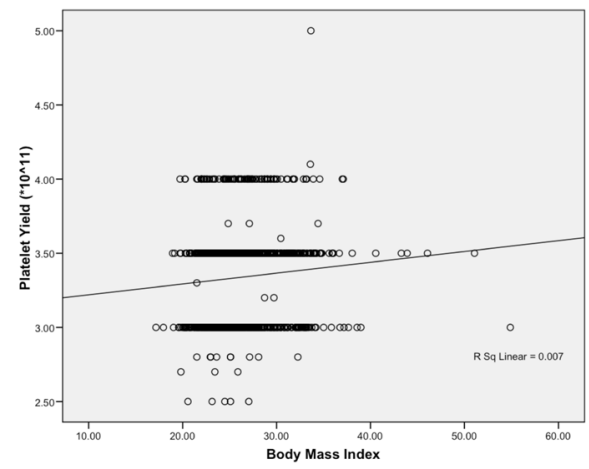

Figure 4: Correlation of Body Mass Index (BMI) with platelet Yield.

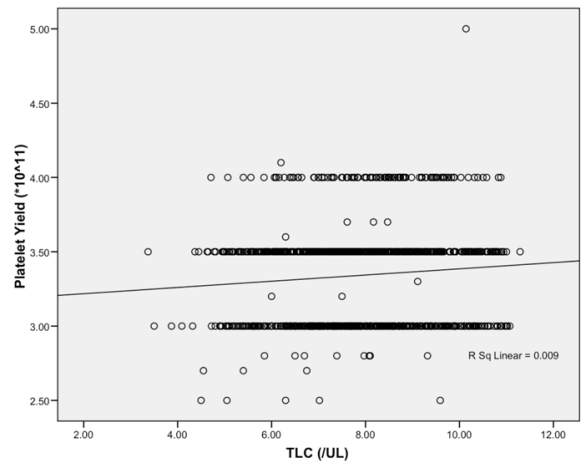

Figure 6: Correlation of Total Leucocytes Count (TLC) with Platelet Yield.

of $26.80 \pm 8.32$. From 1100 donors, there were 1078 (98\%) male donors and $22(02 \%)$ female donors. Age of donors varied from 18 years to 64 years with mean age 30.69 years \pm 6.35 years.

There was statistically significant difference in pre-donation haemoglobin between the genders; with men having significantly higher pre donation haemoglobin (14.77 \pm 1.02 gm \%) than in women $(13.10 \pm 0.66 \mathrm{gm} \%)$. The average values of pre donation haemoglobin was $14.74 \pm 1.04 \mathrm{gm} \%$.

The mean platelet count was $243.01 \pm 55.42$ per $\mu 1$ which 
was higher in females; $257.63 \pm 57.46$ per $\mu$ l than in males; $242.71 \pm 55.37$ per $\mu 1$.

A direct positive correlation was observed between donor's pre donation platelet count and yield of SDP (fig.1) and blood volume processed (fig.2). The $r$ value were 0.189 and 0.577 respectively with $\mathrm{p}<0.001$ while there is a negative correlation between donor's pre donation platelet count and processing time (fig.3) and total volume processed with Pearson value as -0.516 and -0.648 respectively $(p<0.001)$.

Height,weight and BMI had significant correlation with processing time and platelet yield processed. The Pearson correlation between BMI and platelet yield,(fig.4) BMI and processing time (fig.5) are 0.069 and -0.089 respectively $(\mathrm{p}<0.05)$.

Haemoglobin; especially in females; had significant correlation with processing time and blood volume processed $(\mathrm{p}<0.001)$ while no correlation was observed between donor's pre donation haemoglobin and platelet yield $(\mathrm{r}=0.022, \mathrm{p}>0.05)$.

We tried to analyze correlation of Donor's total leucocyte count (TLC) with machine variables and found that total leucocytes count of donor correlated positively with platelet yield and blood volume processed $(r=0.095$ and 0.076 respectively; $\mathrm{p}<0.05$ ) while TLC correlated negatively with processing time and total blood volume processed(r= -0.180 and -0.140 respectively; $<<0.05$ ), findings not observed by any other studies in the literature to the best of our knowledge

$\mathrm{Rh}$ "negative" donors had significant shorter processing time than $\mathrm{Rh}$ "positive" donors $(\mathrm{p}<0.05)$ while $\mathrm{ABO}$ group did not show any correlation with machine variables.

\section{DISCUSSION}

Platelet recovery in the patient is influenced by the transfused dose of platelets, which in turn is dependent on the quality of SDP in terms of platelet yield. The aim of this study was to analyze the impact of various donor and procedure related parameters on platelet yield in 1100 platelet aphaeresis procedures, to optimize platelet yield achieving clinical and economic advantages. Height,weight, BMI, haemoglobin, TLC count, pre-procedure platelet countsand Blood groups were included as donor related variables. Platelet yields, volume processed, processing time were assessed as Procedure related parameters.

There are many reports in medical literature stating that platelet yield is predominantly dependent on the donor platelet count. ${ }^{2,6,7,9,10}$ Goodnough et al studied 708 plateletpheresis procedures performed on 533 donors having mean pre-donation platelet count of $237 \pm 49 \times 10^{3} / \mu 1$ which resulted in platelet product with mean yield of 4.24 $\pm 1.1 \times 10 .{ }^{11}$ A direct linear correlation was observed with all the procedures. ${ }^{2}$ Das SS et al studied 61 plateletpheresis procedures. Pearson correlation of 61 procedures indicated good direct linear correlation between pre-donation platelet count and yield for all procedures $(\mathrm{r}=0.51, \mathrm{P}<$ 0.001). ${ }^{9}$ Guerrero-Rivera et al observed that donor's predonation platelet count had an influence on the platelet yield in the form of positive correlation $(r=0.554$ in group $\mathrm{A}, \mathrm{r}$ $=0.758$ in group B). ${ }^{6}$ Enein AA et al also found that yield correlated positively with platelet pre-count $(\mathrm{r}=0.512) .{ }^{11} \mathrm{~A}$ direct relationship was observed between pre-donation platelet count and yield $(\mathrm{r}=0.50, \mathrm{P}<0.001)$ by ChaudharyR et al. ${ }^{10}$ Patel $\mathrm{J}$ et al performed 265 procedures and found a direct positive correlation between the platelet yield and pre-donation platelet $\operatorname{count}(\mathrm{r}=0.302, \mathrm{p}<0.0001) .{ }^{5}$

In our study,mean pre donation platelet count was 244.14 \pm 55.83 per $\mu 1$ which resulted in platelet product with yield of $3.34 \pm 0.327 \times 10^{11}$. Results of present study were also in accordance with the observations by various studies conducted all over the world. ${ }^{2,6,7,9,10}$ (Table1) and found a direct positive correlation between the platelet yield and pre-donation platelet count $(\mathrm{r}=0.577, \mathrm{p}<0.001)$.

Another donor factor that may have an influence on the platelet yield is pre-donation haemoglobin concentration, which has an inverse relationship with the yield in study done by Guerrero-Rivera et al. ${ }^{6}$ while DasSS et al \&Chaudhary $\mathrm{R}$ et al had observed no correlation of predonation haemoglobin concentration of the donor with yield $(r=-0.05 \& r=-0.1$ respectively, $P>0.005) .{ }^{9}{ }^{910}$ No such correlation was observed in the present study $(\mathrm{r}=0.022$, $\mathrm{p}>0.05$ ) which is similar to the observation by Patel $\mathrm{J}$ et al $(r=-0.001, P>0.005)$,Das SS et al \&Chaudhary R et al..$^{5,9,10}$ while Enein AA et al found that yield negatively correlated with donor pre-aphaeresis haemoglobin $(r=-0.306) .{ }^{11}$

The present study showed correlation of height,weight and BMI with platelet yield $(\mathrm{r}=0.091,0.092$ and 0.069 respectively, $\mathrm{p}<0.05$ ) while Patel $\mathrm{J}$ et al and Chaudhary $\mathrm{R}$ et al did not show correlation between donor's weight $\&$ yield $\left(r=0.023, p>0.005 ; r=0.18\right.$ respectively). ${ }^{5,10}$ Donor's age, sex, did not correlate with platelet yield but $\mathrm{Rh}$ negative donors had significant shorter processing time than $\mathrm{Rh}$ positive donors $(\mathrm{p}<0.05)$ while $\mathrm{ABO}$ group did not show any correlation with machine variables.

According to Enein AA et al and Patel J et al another factor that correlated positively was total volume processed $(\mathrm{r}=0.404 ; \mathrm{r}=0.158, \mathrm{p}<0.05 \text { respectively })^{5,11}$; however increasing the processing time, the ACD infusion rate, or the volume of plasma obtained with platelet can increase platelet yields. ${ }^{11}$ The present study also showed a correlation between donor's total volume processed \& yield $(\mathrm{r}=-0.648$, $\mathrm{p}<0.001)$. 


\section{CONCLUSION}

There are multiple factors affecting the yield of SDP. Predonation platelet count of the donor is the main donor related factor affecting yield of SDP. A pre-donation platelet count is directly related with the yield of SDP and blood volume processed while there is a negative correlation between donor's pre donation platelet count with processing time and total blood volume processed. Platelet yield correlated positively with height, weight and BMI also. $\mathrm{Hb}$ correlated with processing time and blood volume processed but no correlation was observed between donor's pre donation haemoglobin and platelet yield. Donor's age, sex, ABO $\mathrm{Rh}$ did not correlate with platelet yield but $\mathrm{Rh}$ negative donors showed significant correlation with processing time. Donor's TLC correlated positively with platelet yield and blood volume processed while TLC correlated negatively with processing time and total blood volume processed.

Optimization of platelet yield is an emerging issue in blood transfusion services. Identification of such factors may help in selecting donors to obtain higher platelet yields in shorter time and consequently better clinical outcome.

\section{REFERENCES}

1. Wallace EL, Churchill WH, Surgenor DM, Cho GS, McGurk S. Collection and transfusion of blood and blood components in the United States, 1994. Transfusion 1998;38:625-36. CrossRef

2. Goodnough LT, Ali S, Despotis G, Dynis M, DiPersio JF. Economic impact of donor platelet count and platelet yield in aphaeresis products: relevance for emerging issues in platelet transfusion therapy. Vox Sang 1999;76:43-9.CrossRef

3. Chambers LA, Kruskall MS, Pacini DG, Donovan LM. Febrile reactions after platelet transfusion: the effect of single versus multiple donors. Transfusion 1990;30:219-21. CrossRef
4. Gmür J, von Felten A, Osterwalder B, Honegger H, Hörmann A, Sauter $\mathrm{C}$ et al. Delayed alloimmunization using random single donor platelet transfusions: a prospective study in thrombocytopenic patients with acute leukemia. Blood 1983;62:473-9. PMid:6871470

5. Patel J, Nishal A, Pandya A, Patel P, Wadhwani S. Factors influencing yield of platelet aphaeresis using continuous flow cell separator. Int J Med Sci Public Health 2013; 2:309-312. DOI: 10.5455/ ijmsph.2013.2.323-326.[Accessed on 24/07/2013].CrossRef

6. Guerrero-Rivera S, Gutiérrez-Espíndola G, Talavera JO, MeillónGarcía LA, Pedraza-Echevarría M, Pizzuto-Chávez J. Haemoglobin and platelet count effect on platelet yields in plateletpheresis. Arch Med Res 2003;34:120-3. CrossRef

7. Buchholz DH, Squires JE, Herman JH, Ng AT, Anderson JK, Hedberg SL. Plateletpheresis in 90- to 110-pound donors using the CS-3000 blood cell separator. Transfusion1997;37:715-8.CrossRef

8. Drugs and Cosmetic Act 1940. 16th ed. Lucknow : Eastern Book Company; 2003. p.279-303

9. Das SS, Chaudhary RK, Shukla JS. Factors influencing yield of plateletpheresis using intermittent flow cell separator. Clin Lab Haematol2005;27:316-9.CrossRef

10. Chaudhary R, Das SS, Khetan D, Sinha P. Effect of donor variables on yield in single donor plateletpheresis by continuous flow cell separator. Transfus Apher Sci 2006;34:157-61. CrossRef

11. Enein AA, Hussein EA, El Shafie S, Hallouda M. Factors affecting platelet yield and their impact on the platelet increment of patients receiving single donor PLT transfusion. J ClinApher 2007;22:5-9. CrossRef 